\title{
Atmospheric dimethysulphide production from corals in the Great Barrier Reef and links to solar radiation, climate and coral bleaching
}

\author{
Esther Fischer • Graham Jones
}

Received: 26 January 2011/Accepted: 21 February 2012/Published online: 4 March 2012

(C) Springer Science+Business Media B.V. 2012

\begin{abstract}
Coral zooxanthellae contain high concentrations of dimethylsulphoniopropionate (DMSP), the precursor of dimethylsulphide (DMS), an aerosol substance that could affect cloud cover, solar radiation and ocean temperatures. Acropora intermedia a dominant staghorn coral in the Indo-Pacific region, contain some of the highest concentrations of DMSP reported in the literature but no studies have shown that corals produce atmospheric DMS in situ and thus could potentially participate in sea surface temperature (SST) regulation over reefs; or how production varies during coral bleaching. We show that A. intermedia from the Great Barrier Reef (GBR) produces significant amounts of atmospheric DMS, in chamber experiments, indicating that coral reefs in this region could contribute to an "ocean thermostat" similar to that described for the western Pacific warm pool, where significantly fewer coral reefs have bleached during the last 25 years because of a cloud-SST feedback. However, when Acropora intermedia was stressed with higher light levels and seawater temperatures DMSP production, an indicator of zooxanthellae expulsion, increased markedly in the chamber, whilst atmospheric DMS emissions almost completely shut down. These results suggest that during increased
\end{abstract}

E. Fischer · G. Jones ( $\square)$

Marine Ecology Research Centre, School of Environment, Science and Engineering, Southern Cross University, Lismore, NSW 2480, Australia

e-mail: gjones@scu.edu.au light levels and seawater temperatures in the GBR coral shut-down atmospheric DMS aerosol production, potentially increasing solar radiation levels over reefs and exacerbating coral bleaching.

Keywords Dimethylsulphide - Aerosols · Climate change $\cdot$ Coral bleaching $\cdot$ Ocean thermostat . Solar radiation

\section{Introduction}

Concern over increasing emissions of greenhouse gases from fossil fuel combustion and the increased warming this is having on the Earth's climate is leading many coral ecologists to raise concern over increased mass coral bleaching events in the GBR (Harriot 1985; Oliver 1985; Jones et al. 1997; Berkelmans and Oliver 1999; Hoegh-Guldberg 1999; Berkelmans et al. 2004). Whilst GHGs warm the Earth, aerosols also affect climate through cooling and warming the Earth, as well as suppressing rainfall making it drier (Ramanathan et al. 2001; Rathke et al. 2002; Vogelmann et al. 2003). Understanding how aerosols affect climate is one of the biggest uncertainties climate change researchers face, particularly in relation to modelling future projections of temperatures and subsequent effects on marine organisms. A key question for those assessing the effect of climate 
change on coral reefs is how resilient are reefs to rising sea surface temperatures (SSTs), and in light of recent studies, can reefs regulate SST through the production of a DMS-cloud-SST feedback (Jones et al. 1994; Broadbent et al. 2002; Broadbent and Jones 2004, 2006; Jones and Trevena 2005, Jones et al. 2007; Kleypas et al. 2008). It is now believed that SST regulation occurs in the western Pacific warm pool (WPWP) where an "ocean thermostat" keeps the temperature of the reef waters relatively stable (i.e. lower than $30^{\circ} \mathrm{C}$ ) (Ramanathan and Collins 1991; Kleypas et al. 2008). Coral reefs in this region have not bleached so frequently in the last 25 years as other reefs in the wider Pacific Ocean and so a cloud-SST ocean thermostat mechanism has been proposed to keep SSTs within the thermal tolerance levels of corals (Kleypas et al. 2008). The WPWP is a large body of warm water, contains the largest biomass of coral reefs on Earth, and seems to regulate SSTs to $<30^{\circ} \mathrm{C}$ by highly reflective cirrus clouds which act like a thermostat shielding the ocean from solar radiation (Ramanathan and Collins 1991). Emissions of atmospheric DMS from the large number of coral reefs in the GBR, Coral, Solomon and Bismarck Seas to the north east and east of Australia (Fig. 1) may have a significant effect on our regional climate through a DMS-aerosol-cloud link (Jones and Trevena 2005).

Research by our group and others suggests that symbiotic dinoflagellates in corals could take part in such a regional climate feedback since they contain high concentrations of dimethylsulphoniopropionate or DMSP, and reef waters contain high levels of dissolved DMS (Jones et al. 1994; Hill et al. 1995; Broadbent et al. 2002; Jones and Trevena 2005; Van Alstyne et al. 2006; Broadbent and Jones 2006; Jones et al. 2007; Yost et al. 2010; Swan et al. 2012). Furthermore, coral reefs produce huge amounts of coral mucus which concentrate at the air-sea interface and contain very high concentrations of DMS and DMSP (Broadbent and Jones 2004). Air-sea exchange of dissolved DMS in reef waters can produce high levels of atmospheric DMS over reefs (Jones et al. 1994, 2007; Jones and Trevena 2005; Broadbent and Jones 2006), which could oxidise to methansulphonic acid (MSA), sulphur dioxide, and DMS produced sulphate aerosols, leading to the formation of cloud

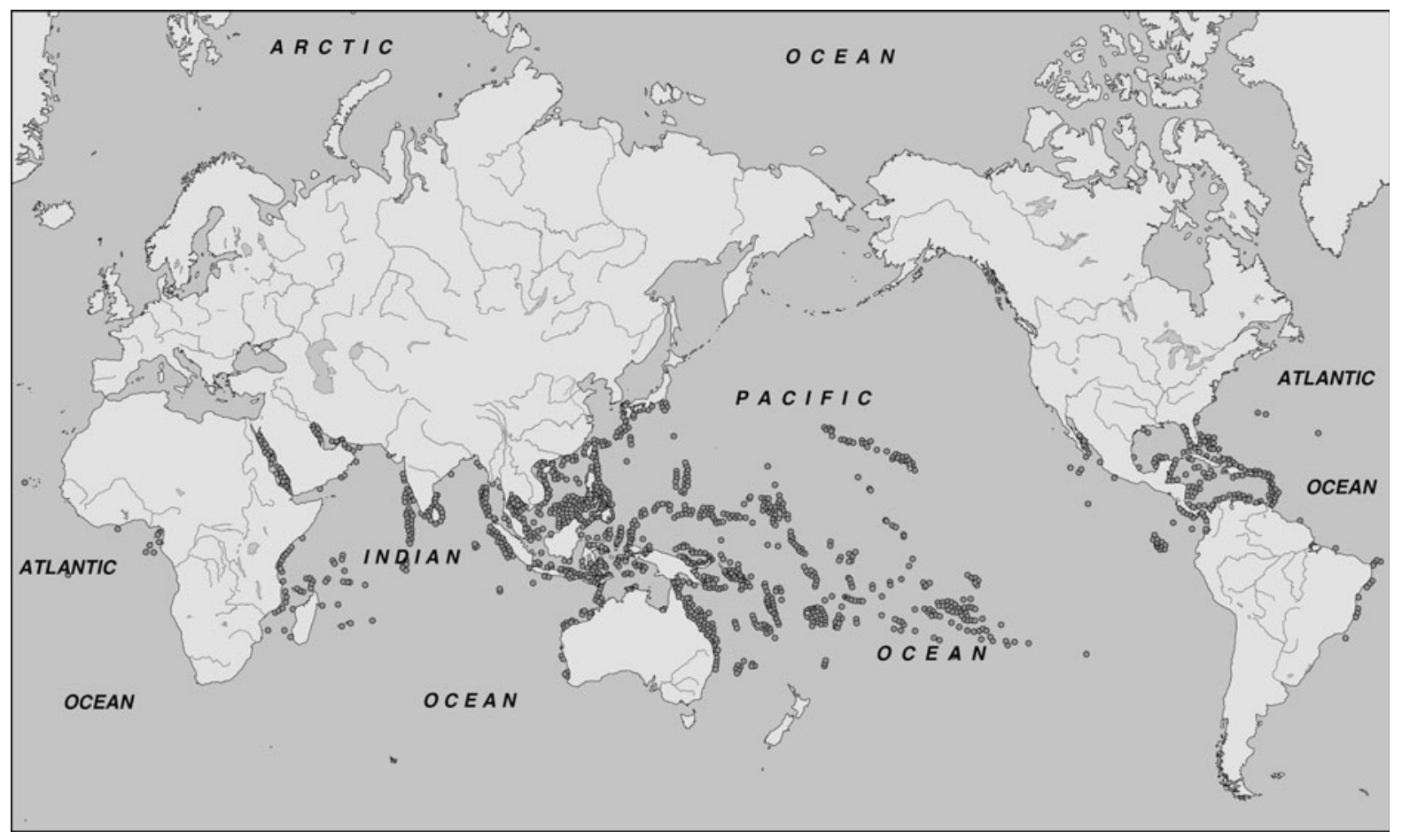

Fig. 1 Global distribution of principal reef regions and coral communities, highlighting the high coral biomass in the western Pacific Ocean to the north and east of Australia. (Source: John Guinotte) 
condensation nuclei $(\mathrm{CCN})$. It has been suggested that these small sulphate aerosol particles attract water vapour to produce low level cumulous clouds, and when CCN numbers are high the albedo (light scattering) of the clouds increases, attenuating solar radiation over the ocean decreasing SSTs (see Charlson et al. 1987; Vallina and Simo 2007, and references therein). But is there any evidence for coral reefs producing atmospheric DMS aerosol particles?

Bigg and Turvey (1978) measured total aerosol particle concentrations of $1,590 \mathrm{~cm}^{-3}$ in the vicinity of extensive coral reefs in the northern GBR from 14 to $17^{\circ} \mathrm{S}, 145-146^{\circ} \mathrm{E}$; much higher than concentrations (mean $640 \mathrm{~cm}^{-3}$ ) measured on the seaward side of the GBR, suggesting coral reefs as the source. These researchers then sampled aerosol particle concentrations on a route between the mainland and the GBR (GBR lagoon) from 17 to $24^{\circ} \mathrm{S}$, in the vicinity of many fringing reefs. The data suggested an extremely broad or distinct source of reef aerosols north of about latitude $25^{\circ} \mathrm{S}$, since the wind was generally east to north-east on the coast and more northly inland (see Fig. 2; Bigg and Turvey 1978). The authors calculated that the emission of aerosol particles from the $1,000 \mathrm{~km}$ length of reefs in the GBR was $\sim 10^{19} \mathrm{~s}^{-1}$, comparable with emissions from land surfaces and forest fires (Table 1). Aerosol concentrations at Heron Island coral cay (Fig. 2, our study site), sampled by Bigg and Turvey from October-mid November, were similar to concentrations in June (Table 1). No analysis of the composition of these aerosols was made by Bigg and Turvey (1978), but maximum aerosol concentrations occurred on the rising tide as we have found for dissolved and atmospheric DMS for reefs in the GBR (Broadbent and Jones 2006; Jones et al. 2007; Swan et al. 2012). A tidal effect on atmospheric DMS over coral reefs has also been reported for the wider western Pacific (Jones and Trevena 2005). In this research we found elevated levels of atmospheric DMS often occur in SE Trade Winds that travel over reefs in the GBR from 14 to $19^{\circ} \mathrm{S}, 146$ to $148^{\circ} \mathrm{E}$ (Jones and Trevena 2005), close to the region sampled by Bigg and Turvey, and could have been the source of the high aerosol particle concentrations measured by these authors.

We have found that atmospheric DMS often increased in the day after low tides and is positively correlated with tidal height, although the correlation is a polynomial relationship, possibly reflecting high concentrations of atmospheric DMS that occur during low tides $(-0.2-1.3 \mathrm{~m})$, and on rising tides over the reefs ( $>1.8 \mathrm{~m}$ ) (Jones and Trevena 2005). This tidal influence on atmospheric DMS (the precursor of nonsea-salt sulphate aerosol particles and $\mathrm{CCN}$ ), occurs over a large area of the GBR, Coral Sea, Gulf of Papua, Solomon and Bismarck Seas (Jones and Trevena 2005). These seas are adjacent to the WPWP, and part of the coral triangle (i.e. coral reefs in waters adjacent to Indonesia, Malaysia, the Philippines, East Timor, Papua New Guinea, Solomon Islands) (McCleod et al. 2010), where $75 \%$ of the Earth's hard corals occur reflecting the huge biomass of coral reefs to the north east and east of Australia (Fig. 1). Kleypas et al. (2008) have identified the WPWP region as displaying an "ocean thermostat" regulation over SSTs in this region and this may be due to the 27 day build-up in cloud cover over reefs in this region, corresponding to a tidal lunar cycle, lowering SSTs and implicating DMS as the source of this cloud cover (Takahashi et al. 2010). This suggestion is supported by recent evidence that shows that coral reefs in the GBR are a source of ammonium sulphate aerosols derived from the oxidation of DMS emitted from coral reefs close to Agnes Water (Modini et al. 2009), a remote coastal site just
Fig. 2 Map of Heron Island showing the location of the sample sites (full circle). (Quickbird image at 00:28:20 h UTC, 3 August 2006 provided by Digital Globe and Centre for Spatial Environmental Research, University of Queensland, Source: Melissa Mackellar)

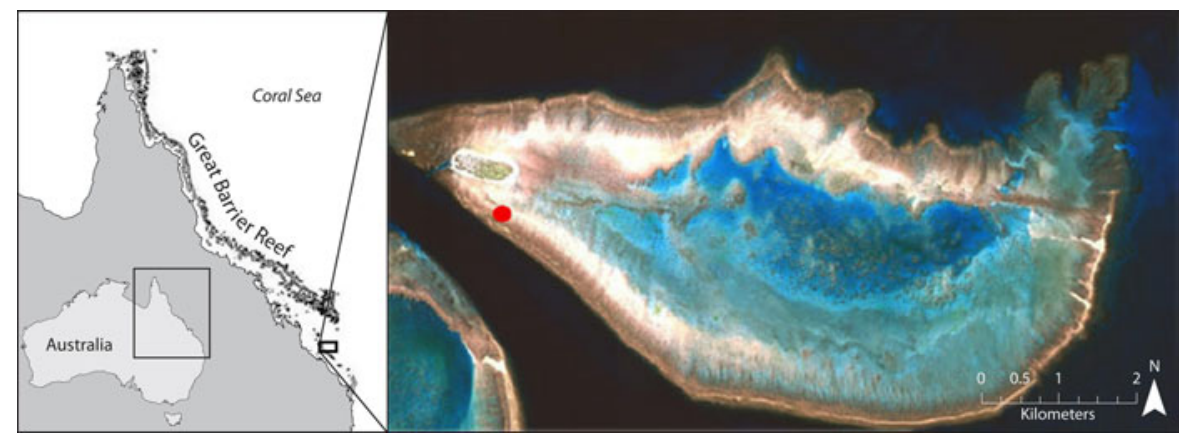


Table 1 Measurements of aerosols over or close to coral reefs in the Great Barrier Reef

\begin{tabular}{llllll}
\hline Location: & $\begin{array}{l}\text { Aerosol } \\
\text { type }\end{array}$ & $\begin{array}{l}\text { Concentration } \\
\left(\mathrm{cm}^{-3}\right)\end{array}$ & Month & Composition & References \\
\hline GBR $\left(14-17^{\circ} \mathrm{S}\right)$ & Marine & 1,590 & June & Unknown & 1 \\
GBR (seaward side) & Marine & 640 & June & Unknown & 1 \\
Australia & Marine & 220 & June & Unknown & 1 \\
GBR $\left(17-24^{\circ} \mathrm{S}\right)$ & Marine & ${ }^{\mathrm{a}} 10^{19} \mathrm{~s}^{-1}$ & June & Unknown & 1 \\
GBR Marine $($ Heron Island & Marine & $\sim 1,600$ & Oct-mid & Exposed corals/stranded algae & 2 \\
$\left.\sim 23^{\circ} 25^{\prime} \mathrm{S}\right)$ & Marine & 3200 & Nov & March & $60 \%$ ammonium sulphate $40 \%$ volatile \\
GBR $\left(24^{\circ} \mathrm{S}\right)$ & Continental & 587 & March & Aitken + Accumulation & 2 \\
GBR $\left(24^{\circ} \mathrm{S}\right)$ & Marine/ & 196 & March & Unknown & 2 \\
GBR & coastal & & & & \\
\hline
\end{tabular}

1. Bigg and Turvey (1978)

2. Modini et al. (2009)

${ }^{a}$ Estimate of particle production calculated from the average enhancement above typical background concentrations, the known mixing depth of $1,350 \mathrm{~m}$, the mean component of the wind speed perpendicular to the aircraft's track and length of track $(1,000 \mathrm{~km})$

south of Gladstone, in the central GBR, close to Heron Island, and where a high biomass of coral reefs occur (Table 1). Modini et al. (2009) measured the strongest nucleation event of a 4 week campaign on 30th March 2007, which was different from all other air masses sampled in that the air mass they sampled that day had travelled over several coral reefs close to Heron Island (our study site). The authors concluded that the GBR was the likely source of the precursor vapours for the freshly formed aerosol particles which consisted of $60 \%$ ammonium sulphate, a known oxidation product of DMS and $40 \%$ organic vapours (Table 1). The particles produced from these reefs grew quickly up to $\sim 80 \mathrm{~nm}$ and is the first direct observation of aerosol particle formation over the GBR. Back trajectories of the air masses analysed indicated that this air mass had travelled over several reefs in the southern GBR and consisted of Aitken $(\sim 80 \mathrm{~nm})$ and Accumulation Mode $(10 \mathrm{~nm})$ aerosol particles. Mean concentrations averaged 3,200 $\mathrm{cm}^{-3}$ and consisted of a broad pulse of aerosol particles emitted from 08.00 to $10.00 \mathrm{~h}$ $\left(1,000-4,500 \mathrm{~cm}^{-3}\right)$, a small discrete aerosol burst at mid-day $\left(1,000-4,000 \mathrm{~cm}^{-3}\right)$, followed by another broad pulse from 14.00 to $16.00\left(2,000-4,000 \mathrm{~cm}^{-3}\right)$ (Modini et al. 2009). From 18.00 to $22.00 \mathrm{~h}$ aerosol concentrations also averaged $\sim 1,000 \mathrm{~cm}^{-3}$. We believe the increase at mid-day could reflect a buildup of dissolved DMS in reefs in the GBR during low tides (Broadbent and Jones 2006) and sea-air exchange to produce atmospheric DMS, which is then oxidised to non-sea salt aerosol particles (i.e. ammonium sulphate). The broad aerosol bursts could have reflected DMS released on the rising tides over the reefs as we have found, although the researchers did not find a linear correlation with the tide. Major sources of this very strong nucleation event include corals, coral reef sediments, macroalgae as well as coral mucus (Broadbent et al. 2002; Broadbent and Jones 2004). Our studies in the western Pacific, where substantial numbers of reefs occur (Fig. 1), indicate that atmospheric DMS often peaks in concentration at mid-day (Jones and Trevena 2005) and we believe this is because a major portion of it is produced during photosynthesis of reef organisms, including corals (Broadbent and Jones 2006). We agree with Modini et al. (2009) that if this particle production occurs along the whole $2,600 \mathrm{~km}$ length of the GBR then it would have a very significant role in regulating the climate of the north Queensland region, and in particular it would have significant effects on solar radiation over the GBR. These sulphur derived aerosol nanoparticles can clearly originate from the oxidation of high levels of atmospheric DMS observed over reefs in this region (Broadbent and Jones 2006; Jones et al. 2007; Modini et al. 2009). In light of these studies (Jones et al. 1994, 2007; Broadbent et al. 2002; Broadbent and Jones 2004, 2006; Bigg and Turvey 1978; Modini et al. 2009) we believe it is vitally 
important to determine whether corals can actually produce atmospheric DMS, since this would suggest that the production of DMS-derived aerosol nanoparticles from reef regions could actually participate in an "ocean thermostat" mechanism over coral reefs as suggested by Kleypas et al. Consequently the principal aims of this study were (1) To see if the coral Acropora intermedia (a staghorn coral) that is very common and widespread in the western Pacific region (Zann 2000) does actually produce atmospheric DMS that could participate in such an ocean thermostat mechanism; (2) Investigate how the production of atmospheric DMS from A. intermedia varies under two different stress treatments of increased light intensity, and elevated seawater temperatures; two stressors that are known to cause coral bleaching (Hoegh-Guldberg 1999; Berkelmans et al. 2004; Kleypas et al. 2008); (3) Investigate whether there is any evidence of SST regulation in the northern and central GBR where the greatest biomass of coral reefs occur.

\section{Methods}

Study site

Field work was carried out in the summer at the Heron Island research station (HIRS) located on Heron Island reef in the southern GBR region (Fig. 2). Located $72 \mathrm{~km}$ northeast of Gladstone $\left(23^{\circ} 25^{\prime} \mathrm{S} 151^{\circ} 55^{\prime} \mathrm{E}\right)$ and $539 \mathrm{~km}$ north of Brisbane, Heron Island is a coral cay covering 18 ha. The coral cay, surrounded by a large platform reef, which drains at low tide, encompasses substantial reef corals, and has a tropical climate, and an average year-round temperature of $\sim 27^{\circ} \mathrm{C}$ (HIRS weather station). Heron Island reef supports extensive colonies of A. intermedia that were used in this study.

\section{Coral collections}

Heron island research station (HIRS) has a large, flowthrough aquarium complex for indoor and outdoor use where seawater is drawn directly from the reef slope providing excellent conditions for conducting experiments with sensitive staghorn corals. Coral nubbins were collected from two colonies of A. intermedia located about $15 \mathrm{~m}$ apart, on the reef slope at about $10 \mathrm{~m}$. The colonies were located around the "Coral Garden" and the "Staghorn Bank" just south of the research station (Fig. 2). These sites were mainly chosen due to the high probability of finding the appropriate coral species, and their close proximity to the research station on the Island (shorter transport times equals less stress for the corals). Corals were collected on snorkel dives during low tide. The tips of each coral branch ( $\sim 5 \mathrm{~cm}$ long) were cut with stainless steel pruning shears. Great care was taken when removing the coral nubbins so as not to damage the tissue of the corals, which would have left the animal prone to bacterial infection. The nubbins were carefully transferred to the indoor research station aquarium system, where they were immediately cut to the required size $(\sim 4 \mathrm{~cm})$ if needed and individually placed into small nubbin holders, which then were placed into a large flow-through seawater tank. The nubbins were left to recover for at least 3 days before using them in experiments and only nubbins that looked healthy after the recovery period (not too pale in colour) were used for the experiments. Low levels of DMSP production in the control experiments, an indicator of zooxanthellae expulsion, indicated that these nubbins were in good condition and were not stressed. DMS released from A. intermedia was measured through direct purging of the coral-derived DMS within a specially designed dosing chamber, and the results were used to calculate the potential of a single coral nubbin to produce atmospheric DMS and hence the flux of DMS from the coral.

\section{Experimental design}

Coral dosing chambers were made out of clear acrylic and consisted of an inner dosing chamber $(2 \mathrm{~mm}$ thickness) for the coral nubbin, and an outer chamber (3 mm thickness) for re-circulating seawater and temperature regulation (Fig. 3). The inner chamber had a stirrer bar operated by a magnet and DC motor for good circulation. Aeration was carried out by an air pump which delivered oxygen to the inner chamber. Average maximum PAR on Heron Island during summer was $\sim 1,700 \mu \mathrm{E} / \mathrm{m}^{2} / \mathrm{s}$ (HIRS weather data), and ambient seawater had a temperature of $24^{\circ} \mathrm{C}$. Control chambers (4 replicates) contained seawater at $24^{\circ} \mathrm{C}$ and were screened to receive natural PAR $\sim 300 \mu \mathrm{E} \mathrm{m}^{-2} \mathrm{~s}^{-1}$; stressed chambers (4 replicates) contained seawater at $26^{\circ} \mathrm{C}$ and were screened to receive natural PAR $\sim 300 \mu \mathrm{E} \mathrm{m}^{-2} \mathrm{~s}^{-1}$; and four chambers received higher ambient sunlight than 
Fig. 3 Coral dosing chamber employed in the experiments

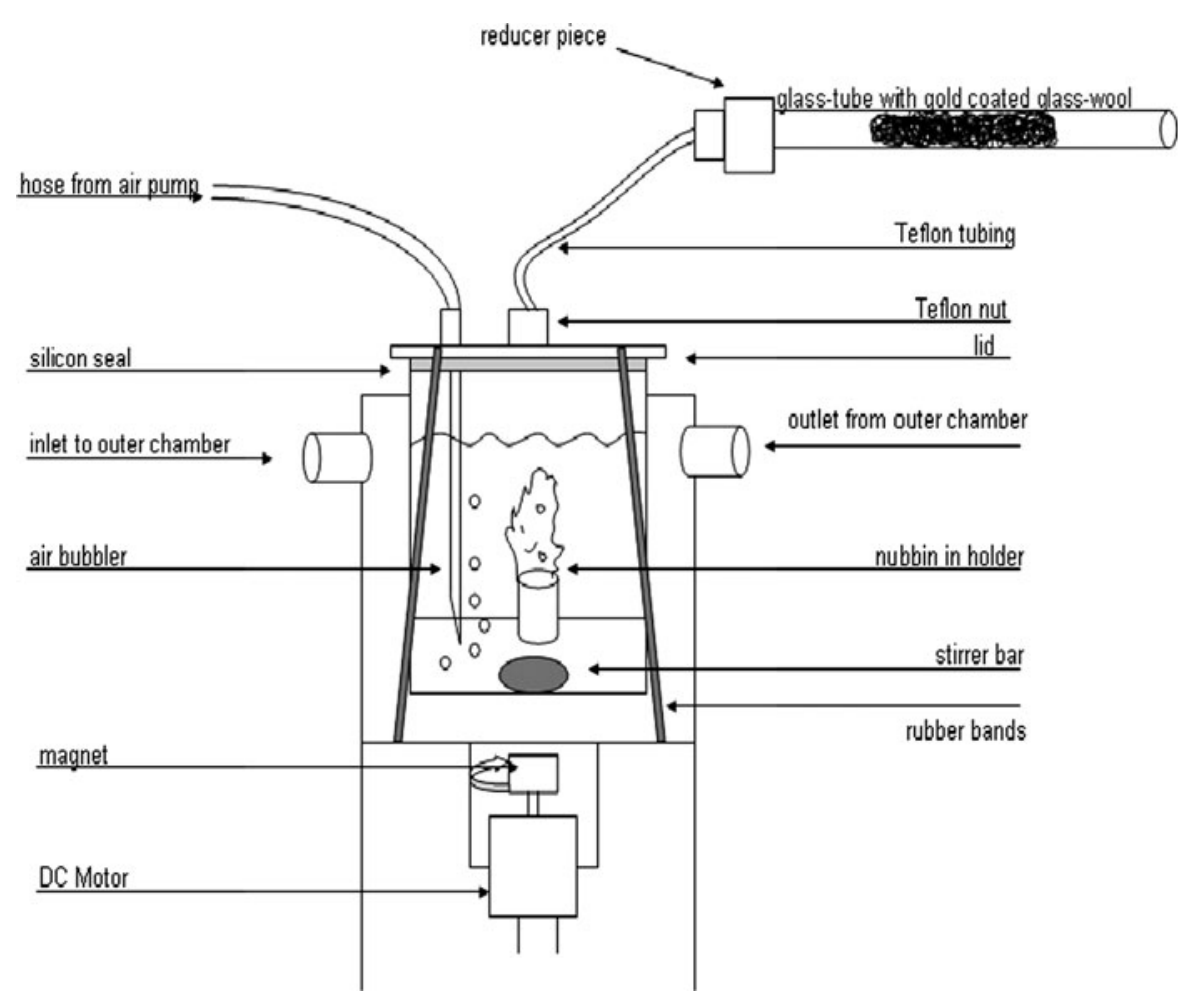

controls at $\sim 1,700 \mu \mathrm{E} \mathrm{m}^{-2} \mathrm{~s}^{-1}$. Seawater temperatures in the outer chamber were regulated with an aquarium thermostat and the inner chamber seawater temperature checked with a temperature thermocouple. Each chamber contained a $4 \mathrm{~cm} \mathrm{~A}$. intermedia coral nubbin which had been cut from the tip of the parent colony and allowed to recover for 3 days, prior to experimentation over $48 \mathrm{~h}$. Atmospheric DMS released from $A$. intermedia was measured every $12 \mathrm{~h}$ through direct purging of the coral-derived DMS onto gold-coated glass wool contained in a quartz tube attached to the chamber and subsequent gas chromatography (Fig. 3), (Curran 1996; Curran et al. 1998). DMSP in the chamber seawater was also measured by gas chromatography (Curran et al. 1998) and is a sensitive measure of coral bleaching (Jones et al. 2007). All nubbins were retained at the end of the experiment and their tissue stripped using an air brush. The resulting tissue slurry was analysed for chlorophyll $a$, zooxanthellae density and total DMSP (= dissolved + particulate DMSP) (see below). In order to normalise the tissue DMSP, chlorophyll $a$ and zooxanthellae data, the surface area of each coral nubbin was determined (see below).
Sampling seawater dosing chambers for total DMSP

A $20 \mathrm{ml}$ seawater sample was taken every $12 \mathrm{~h}$ using a syringe from the inner chambers of the coral dosing system (containing $500 \mathrm{ml}$ seawater) (and replaced with an equivalent volume of seawater used in the experiments), and immediately transferred into an amber glass bottle $(\sim 20 \mathrm{ml})$ which was previously washed in a $10 \% \mathrm{HCl}$ acid solution. The sample was then acidified with a few drops of $32 \% \mathrm{HCl}$ to $\mathrm{pH} 2$ or less which prevented the degradation of total DMSPt to DMS. Random checks of sample vials with $\mathrm{pH}$ indicator paper were conducted to confirm a $\mathrm{pH}$ of $<2$. Samples fixed in such a way can be stored at an ambient temperature for up to 1 year without significant losses and a recovery rate of $100 \%$ can be achieved for samples stored for up to 4 months (Curran et al. 1998).

Analysis of DMSP

DMSPt in A. intermedia tissue and in water samples was analysed using a VARIAN CX 3400 
Gas Chromatograph fitted with a flame photometric detector (FPD) following the method based on the 1:1 alkali cleavage of DMSP to DMS (Curran et al. 1998). The GC was calibrated every day using a 4 point calibration of acidified DMSP working standards $(3,6,15,30 \mathrm{ngS})$ which were made up by serial dilution from a DMPT (Research Plus Inc., New Jersey, USA) stock standard. Additional control standards were run at the end of the day and at random intervals during the day to check accuracy. A second calibration was carried out if the control standards varied by more than $\pm 5 \%$. The detection limit for DMS was found to be $0.15 \mathrm{nM}$. In order to maintain the stability of the system, the GC was left on overnight with all gasses left running. VARIAN Star software (version 6) was used to quantify the DMS peak area, and the concentration of DMSP (nM) in each sample was calculated from the volume injected and the obtained sulphur mass. DMSP production from Acropora in the chamber was calculated from the difference in DMSPt concentrations between two time points, divided by the time between these points (i.e. $12 \mathrm{~h}$ ) and expressed per $\mathrm{cm}^{2}$ of coral surface area (see below).

\section{DMS flux measurements}

Flux measurements were made by analysing the atmospheric or headspace DMS concentration found on the "gold tubes" (Curran et al. 1998), (Fig. 3) resulting from the air-sea exchange of dissolved DMS over a $12 \mathrm{~h}$ period and expressing this concentration in terms of the coral surface area per day. This measurement differs from dissolved DMS measurements whereby samples of seawater are directly purged onto the gold tubes immediately after collection and which are not undergoing air-sea exchange over a $12 \mathrm{~h}$ period. In our measurements DMS underwent air-sea exchange directly onto the gold tubes placed above the seawater in the chambers over $12 \mathrm{~h}$ and reflects a measurement of DMS produced from Acropora which is transferred to the headspace or atmosphere of the chamber by continuously bubbling the chamber seawater. These measurements simulate air sea exchange at the reef crest and are therefore an estimate of atmospheric DMS concentrations that undergo air-sea exchange at the reef crest.
Coral tissue analysis

Immediately at the end of each experimental run (at $48 \mathrm{~h}$ ), each nubbin was placed in an individual labelled plastic bag $(15 \times 10 \mathrm{~cm})$. The bags were put into a freezer at $-20^{\circ} \mathrm{C}$ for $2-4 \mathrm{~h}$, to facilitate the removal of the tissue. In order to have more control over the amount of water used during the removal of the tissue, it was decided to remove the tissue by air blasting rather than water piking. For this, an air gun was attached to the $\mathrm{BC}$-hose of a SCUBA regulator set which was attached to a compressed air dive-cylinder. To further narrow the stream of air coming out of the gun, a $1 \mathrm{ml}$ micropipette tip was fitted to the tip of the air gun, which would also cause an increase in the pressure of the airflow. The tissue was then removed from the coral skeleton by directing the pressurised airflow onto the nubbin, which was firmly held in place by a set of tweezers. In order to minimise spray during the tissue stripping process, a special beaker with a cut-out in one side was used, and the coral nubbin was held against the back wall of the beaker. The nubbin was moistened regularly with filtered seawater during the stripping process to allow for complete removal of the coral tissue from the skeleton. The obtained tissue slurry was then homogenised using a Mystral $^{\mathrm{TM}}$ hand blender and made up to $40 \mathrm{ml}$ with filtered seawater. The sample was then sub-sampled for chlorophyll $a(2 \times 10 \mathrm{ml})$, zooxanthellae counts $(10 \mathrm{ml})$ and tissue analysis of DMSP $(4 \mathrm{ml})$. Storage of DMSPt in coral tissue samples was carried out in a similar way to the seawater samples, with the only difference being that $4 \mathrm{ml}$ of the tissue slurry was transferred into $5 \mathrm{ml}$ amber screw cap vials to which a few drops of $32 \%$ hydrochloric acid was added. DMSP measurements were then determined by gas chromatography (Curran et al. 1998).

\section{Chlorophyll $a$ analysis}

The chlorophyll sub-sample containing the diluted tissue slurry was filtered through a $2.5 \mathrm{~cm} \mathrm{GF/F} \mathrm{filter}$ (Whatman Cat. No. 1825 025) which was then submerged in $10 \mathrm{ml}$ of $90 \%$ acetone and placed in a freezer $\left(-18^{\circ} \mathrm{C}\right)$ for $24 \mathrm{~h}$. The samples were centrifuged the next day for about $10 \mathrm{~min}$ at $1,500 \mathrm{rpm}$ and absorbance measured at 630, 647, 664 and $750 \mathrm{~nm}$ using a SHIMADZU UV-2401 PC UV-VIS recording spectrophotometer connected to a PC, running 
Windows $95^{\mathrm{TM}}$. Chlorophyll a concentration was calculated using the following formula described by Jeffrey and Humphrey (1975).

$$
\begin{aligned}
{[\text { Chlorophyll a }]=} & 11.85\left(A_{664}-A_{750}\right) \\
& -1.54\left(A_{647}-A_{750}\right) \\
& -0.8\left(A_{630}-A_{750}\right)
\end{aligned}
$$

The concentration in $\mu \mathrm{g} \mathrm{ml}^{-1}$ was then multiplied by a factor 40 used in sample dilution and corrected for surface area to obtain the chlorophyll concentration in $\mu \mathrm{g} \mathrm{cm}^{-2}$ surface area of the coral nubbin.

\section{Zooxanthellae counts}

Zooxanthellae were counted using an improved Neubaur haemocytometer. The haemocytometer is a modified microscope slide comprising of two polished surfaces, each of which displays a precisely ruled, subdivided grid. The plane of the grid rests $0.1 \mathrm{~mm}$ below two ridges that support a sturdy coverslip. Zooxanthellae were counted in the four large outside squares. These squares each have an area of $1 \mathrm{~mm}^{2}$ so that the total area counted was $4 \mathrm{~mm}^{2}$. The volume of the fluid is $1 \mathrm{~mm}^{2}$ (area of one square) $\times 4$ (no. of square counted) $\times 0.1 \mathrm{~mm}^{2}$ (depth). Cells touching the upper and left-hand boundary lines of the main squares were counted, while those touching the lower and right-hand boundary lines were not counted. The haemocytometer was loaded using a $10 \mu \mathrm{l}$ glass syringe, so that the fluid entirely covered the polished surface of the chamber and great care was taken so as not to overload the counting chambers. The chamber was loaded three times and zooxanthellae in all four outside squares were counted using a hand tally counter while viewing the chamber with an Olympus CHT compound microscope at a magnification of $100 \times$. Both the haemocytometer and the coverslip were cleaned with MilliQ ${ }^{\mathrm{TM}}$ water and blotted dry in between each loading. The zooxanthellae measurements were then used with the DMSP concentrations in the coral tissue to give the zooxanthellar or cell-specific DMSP concentration.

Coral surface area measurements

In order to normalise the DMSPt, chlorophyll $a$ and zooxanthellae data, the surface area (the area covered by the coral tissue) of each nubbin was determined using the method described by Chancerelle (2000).
Statistics

Both Microsoft Excel ${ }^{\mathrm{TM}}$ XP and SPSS 11 were used for the statistical analyses of the data sets. Excel was used for descriptive statistics including the calculation of means and standard errors, as well as plotting graphs. For the tissue data, statistically significant differences between treatments were determined with a Multivariate Analysis of Variance (MANOVA) using SPSS 11, and significance was determined at the 0.05 level. Water data were analyzed with a fully factorial repeated measures analysis in SPSS 11 and significance was again determined at the 0.05 level.

Sea surface temperatures on the GBR

Monthly seawater SSTs in the GBR from 1958 to 1992 were extracted from the Comprehensive OceanAtmosphere Data Set (COADS, Jones 1995). This data set is based on averages of observations from all ships-of-opportunity for a particular month, within a $2 \times 2^{\circ}$ latitude-by-longitude areas of the world's oceans. Average annual, summer (October-March), and winter (April to September), SSTs were determined for the areas between 10 and $24^{\circ} \mathrm{S}$ encompassing the GBR (see Figs. 3, 6). SSTs in three additional $2 \times 2^{\circ}$ boxes were also examined for the areas immediately to the south of the GBR, between latitudes $24-30^{\circ} \mathrm{S}$.

\section{Results}

\section{Chamber experiments}

For control corals used in this experiment atmospheric DMS production was $2.3-4.9$ pmol cm $\mathrm{cm}^{-2} \mathrm{~h}^{-1}$ (mean 3.5), with lowest concentrations emitted in the first dark period (18.00-06.00), and higher concentrations over the first light period (06.00-18.00) (Fig. 4A), agreeing with field measurements at reefs (Jones et al. 2007). This cycle of higher levels in the light period than the dark period was maintained in the second $24 \mathrm{~h}$ cycle, although the variation about the mean was higher for measurements made in the light period. DMSP production (a measurement of zooxanthellae expulsion) in control chambers slowly decreased from $0.48 \mathrm{pmol} \mathrm{cm}^{-2} \mathrm{~h}^{-1}$ to $0.38 \mathrm{pmol} \mathrm{cm} \mathrm{cm}^{-2} \mathrm{~h}^{-1}$ (mean 0.43 ) (Table 2) over the course of the experiment, 

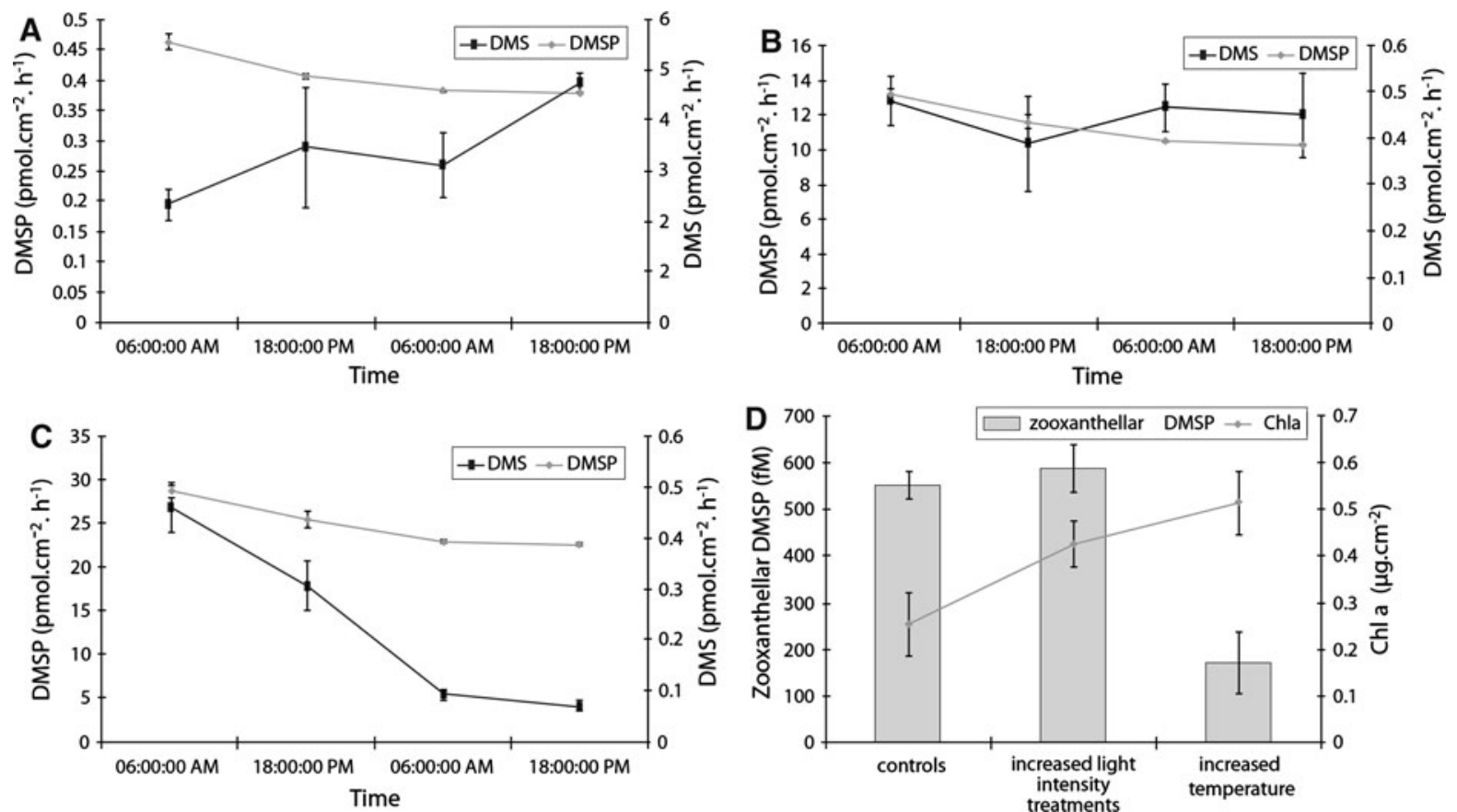

Fig. 4 DMSP production (pmol $\mathrm{cm}^{-2} \mathrm{~h}^{-1}$ ) and atmospheric DMS production ( $\mathrm{pmol} \mathrm{cm}^{-2} \mathrm{~h}^{-1}$ ) from A. intermedia for A control corals at $24^{\circ} \mathrm{C}$ and low light (shade cloth), B corals exposed to increased light intensity (no shade cloth) at $24^{\circ} \mathrm{C}$,

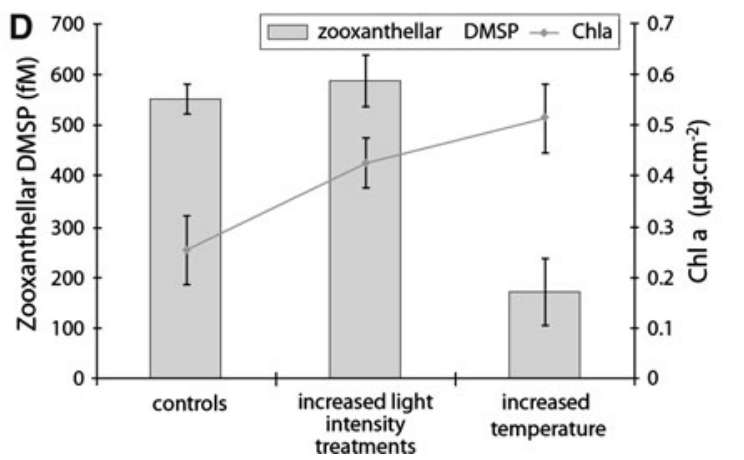

and $\mathbf{C}$ corals exposed to elevated seawater temperatures of $26^{\circ} \mathrm{C}$ and low light (shade cloth), D zooxanthellar DMSP (fmol) and chlorophyll $a\left(\mu \mathrm{g} \mathrm{cm}^{-2}\right)$ measured in the control and stressed coral tissues at the end of the experiment

indicating that the coral was not significantly stressed in shaded light and ambient seawater temperatures. Under higher light intensities atmospheric DMS production was fairly constant over the $48 \mathrm{~h}\left(0.4-0.5 \mathrm{pmol} \mathrm{cm}{ }^{-2} \mathrm{~h}^{-1}\right.$, mean 0.45$)$, with production much lower $(87 \%)$ than controls. This could have reflected increased photochemical oxidation of DMS to DMSO under these higher light levels as high levels of DMSO have been recorded

in reefs (Jones et al. 2007), as well as being detected in previous chamber experiments with corals. DMSP production under high light intensities was about 30 times higher than production from control corals (range 10-13 pmol cm ${ }^{-2} \mathrm{~h}^{-1}$; mean 11.5) and slightly decreased over the $48 \mathrm{~h}$ period (Fig. 4B). When A. intermedia nubbins were stressed by a $2^{\circ} \mathrm{C}$ increase over the ambient seawater temperature of $24^{\circ} \mathrm{C}$, DMSP

Table 2 Hourly production rates of DMSP and atmospheric DMS released from A.intermedia nubbins normalised to coral surface area, for control corals, corals stressed by increased light intensity, and elevated temperatures

\begin{tabular}{lllll}
\hline Experiment & Measurement & DMSP $\left(\mathrm{pmol} \mathrm{cm}^{-2} \mathrm{~h}^{-1}\right)$ & DMSa & $\mathrm{DMSa} \mathrm{flux}\left(\mu \mathrm{mol} \mathrm{m}^{-2} \mathrm{~d}^{-1}\right)$ \\
\hline Controls & Mean & 0.43 & 3.5 & 0.84 \\
& Range & $0.38-0.48$ & $2.3-4.9$ & $0.55-1.13$ \\
& $n$ & 16 & 16 & 16 \\
Increased light intensity & Mean & 11.5 & 0.45 & 0.11 \\
& Range & $10-13$ & $0.4-0.5$ & $0.1-0.12$ \\
& $n$ & 16 & 16 & 16 \\
Increased temperature $\left(+2^{\circ} \mathrm{C}\right)$ & Mean & 26.5 & 0.24 & 0.06 \\
& Range & $23-28$ & $0.08-0.46$ & $0.02-0.11$ \\
& $n$ & 16 & 16 & 16 \\
\hline
\end{tabular}

For comparison with literature data, daily DMS production rates normalised to coral surface area are also reported 
production was at its highest levels encountered in the study (range 23-28 pmol cm ${ }^{-2} \mathrm{~h}^{-1}$, mean 26.5) and steadily decreased over the $48 \mathrm{~h}$ (Fig. 4C). In contrast to the other two experiments (controls and light stress) atmospheric DMS production from temperature stressed corals was considerably lower (range 0.08-0.46 pmol cm ${ }^{-2} \mathrm{~h}^{-1}$; mean 0.24) and decreased to almost no production of atmospheric DMS after 36 and $48 \mathrm{~h}$ (Fig. 4C).

Tissue DMSP levels in control corals (473-601 nmol cm $\mathrm{cm}^{-2}$ ) was much higher than in temperature affected coral tissues $\left(57-256 \mathrm{nmol} \mathrm{cm}^{-2}\right.$ ) $(P<0.05)$ reflecting coral bleaching and increased loss of zooxanthellae to the chamber seawater for temperature stressed corals. Differences between tissue DMSP in control corals and light-affected corals was small (light stressed DMSP ranged from 439 to $680 \mathrm{nmol} \mathrm{cm}^{-2}$ ). Consequently zooxanthellar DMSP in control and light-treated corals were closely similar (control corals $=550 \mathrm{fmol}$ zooxanthellae ${ }^{-1}$; lighttreated corals $=580 \mathrm{fmol}$ zooxanthellae ${ }^{-1}$; Fig. 4D), and reflected the slightly higher zooxanthellae densities in light affected corals $\left(1.01 \mathrm{E}+06 \mathrm{~cm}^{-2}\right.$ lightaffected versus controls $9.37 \mathrm{E}+05 \mathrm{~cm}^{-2}$ ). This was not the case during higher seawater temperatures when zooxanthellae densities markedly decreased to $7.63 \mathrm{E}+05$ and zooxanthellar DMSP decreased to $160 \mathrm{fmol}$ zooxanthellae ${ }^{-1}$ (Fig. 4D). Chlorophyll $a$ levels increased from $0.28 \mu \mathrm{g} \mathrm{cm}^{-2}$ in control nubbins, to $0.43 \mu \mathrm{g} \mathrm{cm}^{-2}$ (increased light), and almost doubled to $0.52 \mu \mathrm{g} \mathrm{cm}^{-2}$ in temperature affected corals $(P<0.5$; Fig. 4D). We have found DMSP concentrations in zooxanthellae from Acropora species from the GBR range from 171 to 3,831 fmol cell ${ }^{-1}$ (Broadbent et al. 2002) so total DMSPt (i.e. dissolved + particulate DMSP $=\mathrm{DMSPt}$ ) production in the chambers is a good proxy of zooxanthellae expulsion. In chamber experiments with $A$. formosa (a related coral species to A. pulchra) we have found that it produces about 456 pmol DMS-S polyp ${ }^{-1}$ day $^{-1}$ which equates to about $0.3 \%$ of the sulphur content of the coral, in agreement with estimates of actual zooxanthellae released from A. formosa (Broadbent and Jones 2006; Jones et al. 2007). This supports our assertion that DMSPt measurements in chambers with Acropora spp is a proxy of zooxanthellae expulsion, and when stress is applied, a good indicator of coral bleaching, since corals release zooxanthellae containing DMSP during these conditions (Broadbent and Jones 2006).
DMS flux from the chambers

Mean production rates of DMS in the experiments were used to calculate the daily flux of DMS from corals (Table 2). DMS flux from Acropora from the control chambers averaged close to $1 \mu \mathrm{mol} \mathrm{m} \mathrm{m}^{-2} \mathrm{~d}^{-1}$. During increased light intensity and seawater temperature the flux of atmospheric DMS from the coral decreased by $87 \%$ (light affected) to $93 \%$ (almost a complete shut-down) when temperatures were increased by only $2^{\circ} \mathrm{C}$ above ambient seawater temperatures of $24^{\circ} \mathrm{C}$ (Table 2). Clearly our control chamber experiments indicate that for coral reefs that are dominated by Acropora sp. (staghorn coral) atmospheric DMS produced by such reefs could participate in oxidation processes that produce aerosol nanoparticles such as non-sea salt sulphate aerosols and CCN (Bigg and Turvey 1978; Modini et al. 2009), and could possibly take part in a negative feedback to lower SSTs (Charlson et al. 1987). However, when corals are stressed by elevated SSTs and higher light levels, above certain thresholds, corals decrease the production of atmospheric DMS, which could increase solar radiation over reefs and increase SSTs (a positive feedback). However, is there any evidence for SST cooling (negative feedback) in the GBR, similar to that reported for the WPWP where a DMS-cloud albedo link is clearly implicated (Kleypas et al. 2008).

\section{Evidence for SST cooling in the GBR}

COADS SST (Comprehensive Ocean-Atmosphere Data Set) data suggest that SSTs over most of the GBR have not increased significantly over the period 1958-1992. The more northerly sections $\left(10-20^{\circ} \mathrm{S}\right)$ generally show a slight cooling for yearly and summer periods, although the trend is weak (Fig. 5). From 10 to $20^{\circ} \mathrm{S}$ the COADS data suggests that the yearly cooling trend is quite consistent, although small $\left(-0.04\right.$ to $\left.-0.29^{\circ} \mathrm{C}\right)$, with the yearly and summer cooling trend between 14 and $16^{\circ} \mathrm{S}$ much more pronounced $\left(-0.29^{\circ} \mathrm{C}\right)$. In the $14-16^{\circ} \mathrm{S}$ region concentrations of DMS aerosols from reefs from the central and southern GBR $\left(16-24^{\circ} \mathrm{S}\right)$ would be transported to the northly section of the GBR since the SE Trades would direct reef aerosols in this general direction (Fig. 2). In contrast, the mean annual SST between latitudes $24-26^{\circ} \mathrm{S}$, where reefs do not occur, increased significantly $\left(+0.63^{\circ} \mathrm{C}\right)$ between 1958 and 


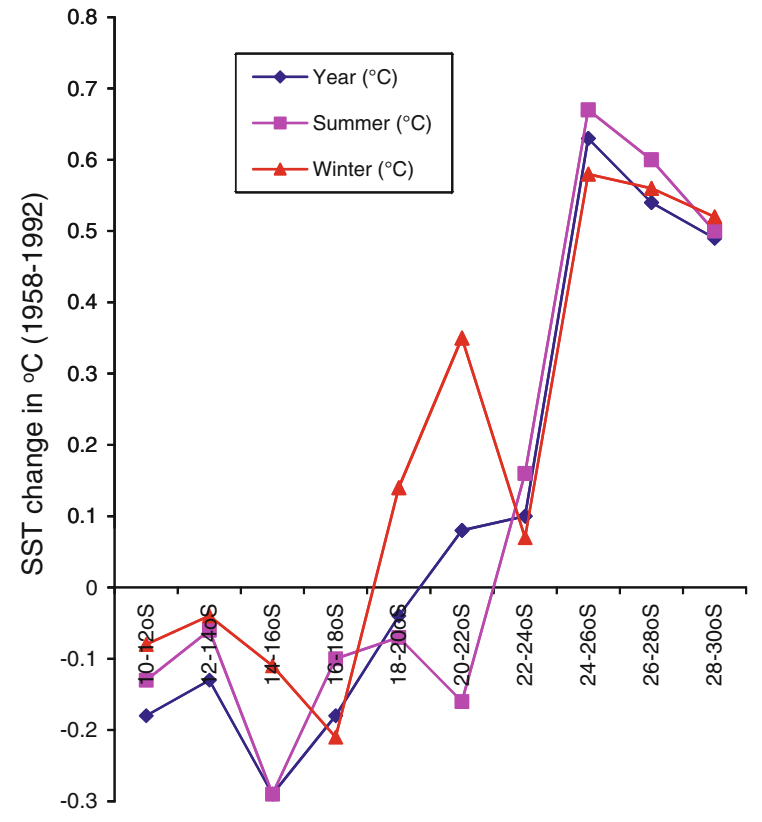

Fig. 5 Overall change in yearly, summer and winter SST from 1958 to 1992 . [The increased warming from 24 to $30^{\circ} \mathrm{S}$ is significant $(P<0.05)$, whilst from 10 to $20^{\circ} \mathrm{S}$ the trend is not significant $(P<0.05)]$

1992. This temperature increase has occurred through significant changes in both summer and winter temperatures (Fig. 5). Similar increases in average annual SST in the area immediately to the south of the GBR, between latitudes $26-30^{\circ} \mathrm{S}$, have also been recorded in both summer and winter temperatures (Fig. 5). A slightly more extended SST record for the GBR from 1950 to 2007 exhibits a significant and enhanced warming trend along the whole NE coast of Australia from 10.5 to $28.5^{\circ} \mathrm{S}$ (Lough 2008), confirming the much hotter conditions during the last decade or so. However, this researcher found that the reef area from 10.5 to $14.5^{\circ} \mathrm{S}$ in the northern GBR is not warming as fast as the region from 14.5 to $28.5^{\circ} \mathrm{S}$, which supports the COADS data of a cooling trend in this northly GBR region.

Clearly more research needs to be undertaken to ascertain whether there is a significant cooling trend in the northern GBR, particularly in the region of $14-16^{\circ} \mathrm{S}$ where DMS aerosol particles from southerly reefs could concentrate, and establish whether this cooling trend could be due to a climate feedback that involves DMS production from coral reefs and oxidation to non-sea-salt sulphate aerosol particles and CCN (Jones et al. 1994, 2007;
Broadbent et al. 2002; Broadbent and Jones 2004, 2006; Jones and Trevena 2005). However, our stress experiments suggest that this climate aerosol feedback, if it occurs, could be compromised by only small increases in SSTs of about $2^{\circ} \mathrm{C}$ above ambient temperatures.

\section{Discussion}

Shut-down in atmospheric DMS production from corals

Our stress experiments indicate that during elevated SSTs atmospheric DMS production decreased rapidly every $12 \mathrm{~h}$ to $\sim 80 \mathrm{fmol} \mathrm{cm}^{-2} \mathrm{~h}^{-1}$, compared with a maximum production of $\sim 5,000 \mathrm{fmol} \mathrm{cm}^{-2} \mathrm{~h}^{-1}$ after $48 \mathrm{~h}$ in control corals (Fig. $4 \mathrm{a}$ ). We believe this shut-down in production of atmospheric DMS reflects the use of DMS as an antioxidant in the coral zooxanthellae (Sunda et al. 2002; Jones et al. 2007; Yost et al. 2010; Deschaseaux et al. 2012) and perhaps explains why DMSO is often the highest sulphur substance measured in coral reef waters (Broadbent and Jones 2006), and why we see DMSO in some of our coral chamber experiments (unpublished). This would occur if DMS is being oxidised in the coral by the increase in oxygen free radicals in the stressed coral tissue (see refs in Jones et al. 2007). This decreased production of atmospheric DMS coincided with a marked decrease in tissue DMSP, zooxanthellar DMSP and an increase in chlorophyll a (Fig. 4D). The decrease in tissue DMSP reflected an increase in zooxanthellae expulsion (bleaching) from Acropora into the chamber during the light and temperature stress. However, it is reasonable to assume that this would also decrease the tissue concentration of chlorophyll a, and this did not occur, it increased. We believe this may be due to the "shuffling" of different clades of zooxanthellae in the coral which have different concentrations of chlorophyll a (Berkelmans and van Oppen 2006) and DMSP (unpublished). More importantly our research suggests that under conditions of elevated SST the amount of atmospheric DMS produced by coral reefs starts to decrease, potentially resulting in lower aerosol production, decreased cloud cover, elevated solar radiation and SSTs, the reverse of the CLAW hypothesis (Charlson et al. 1987). 
Evidence for regional increase in solar radiation over reefs in the GBR

A 10 year solar radiation climatology developed for the GBR $\left(10-26^{\circ} \mathrm{S}, 142-155^{\circ} \mathrm{E}\right)$ region using data from the geostationary meteorological satellite (GMS) from 1995 to 2005 (Masiri et al. 2008) shows that the summer and autumn solar radiation levels exhibit distinct maxima and high solar radiation levels in the southern end of the study area, between latitudes $18^{\circ} \mathrm{S}$ (just north of Townsville) to $26^{\circ} \mathrm{S}$ (southern most reefs of the GBR) (Fig. 6).

During summer, this region has solar radiation levels larger than $30 \mathrm{MJ} \mathrm{m}^{-2}$ day $^{-1}$, while northern regions $\left(\sim 10-18^{\circ} \mathrm{S}\right)$ have solar radiation levels that are considerably lower, typically $24 \mathrm{MJ} \mathrm{m}^{-2}$ day $^{-1}$. This feature persists in autumn and spring but is minimal during the dry cloudless season in winter, when DMS production from reefs would normally be low (Jones et al. 2007). This solar irradiance feature
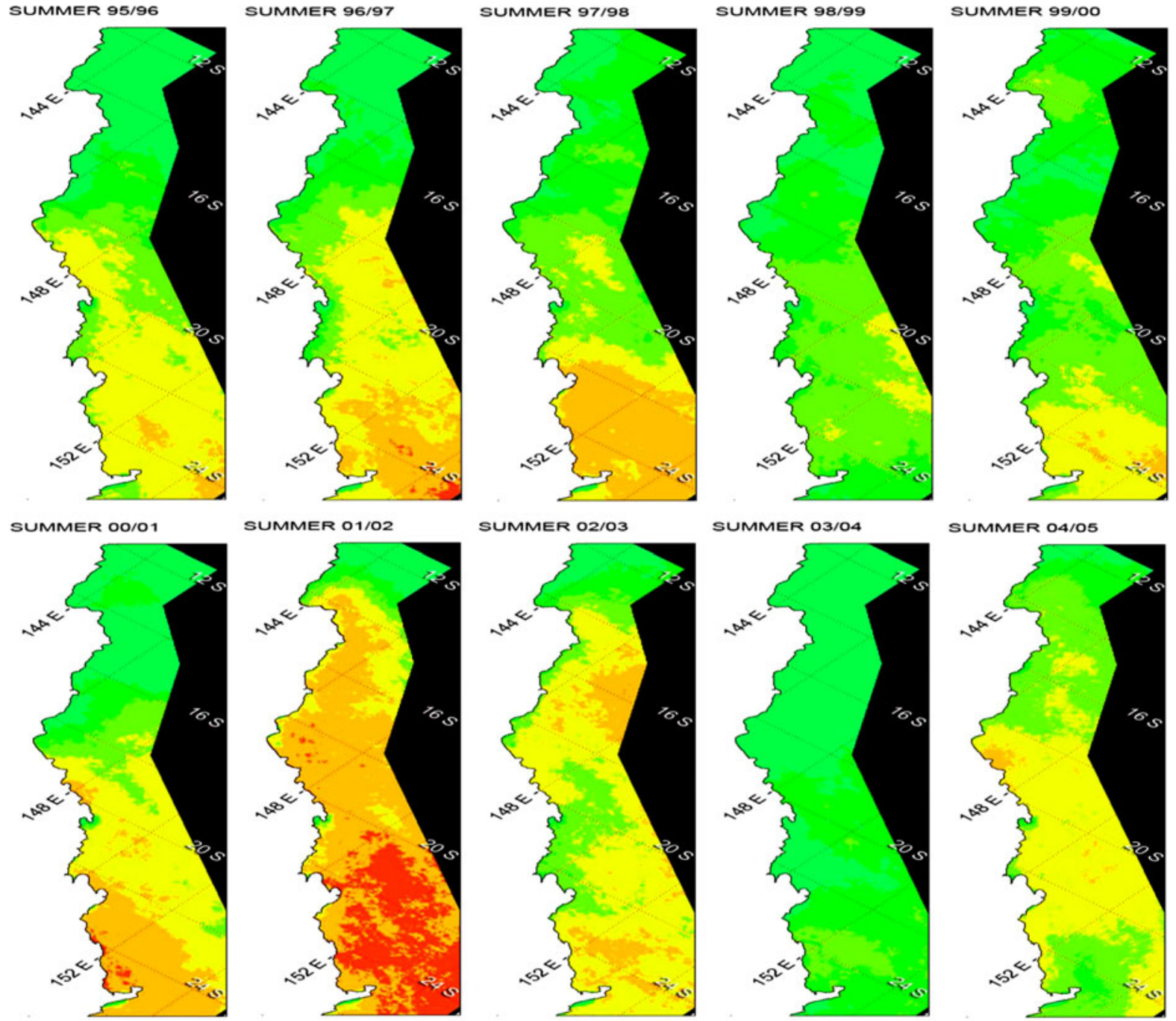

SUMMER 03/04

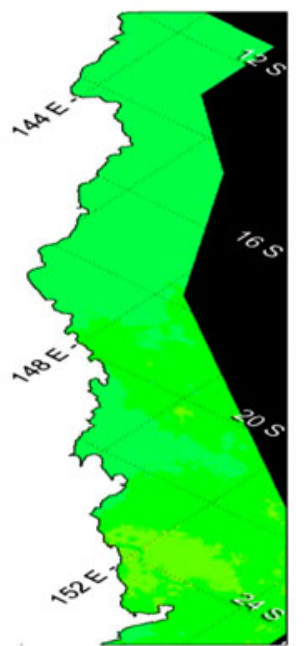

SUMMER 04/05

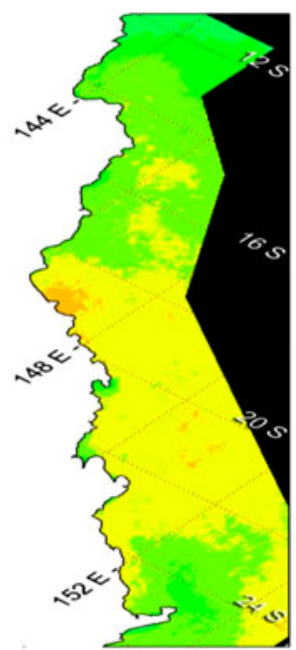

$\frac{1}{25} 2627 \quad \frac{1}{\mid} \mid \frac{1}{\mid}$ $m u-m^{2}-d a y+$

Fig. 6 Daily average solar radiation levels over the Great Barrier Reef for the months of November to April for the period 1995-2005 (Source: Evan Weller, University of Tasmania) 
over the GBR could be influenced by the alignment of the reef to the coast, prevailing wind direction and the seasonal influence on DMS production from reefs in the GBR (Jones et al. 2007).

Masiri et al. (2008) concluded that cloud cover influences both seasonal and yearly patterns of solar radiation as a north-south latitudinal gradient, which could be a reflection of the latitudinal change in coral biomass and variations in reef aerosol emissions. These authors also examined the yearly trend in solar radiation and found that solar radiation levels have increased over the GBR by just under $1 \%$ per decade, coinciding with mass coral bleaching episodes in the GBR.

Solar radiation during mass coral bleaching episodes

Masiri et al. (2008) averaged the high daily solar radiation values over the high radiation months (November-February) for a $200 \mathrm{~km}$ strip of the GBR coast, and showed that maximum daily solar radiation levels coincided with severe coral bleaching episodes within the 1995-2005 period. Two mass coral bleaching episodes occurred in this time frame, one occurring in the summer of 1998 and the second in 2002 (Fig. 6) (Berkelmans and Oliver 1999; Berkelmans et al. 2004). It can be clearly seen that the summer of 2001/2002, when many reefs bleached in the GBR, the highest daily solar radiation levels occurred in the region bounded by $12-24^{\circ} \mathrm{S}$ (Fig. 6) with levels in excess of $29 \mathrm{MJ} \mathrm{m}^{-2}$ day $^{-1}$. A very large region in the southern part of the GBR had solar radiation levels in excess of $30 \mathrm{MJ} \mathrm{m}^{-2}$ day $^{-1}$ where the greatest biomass of coral reefs occur (Fig. 2). When focussing on the daily average solar radiation levels from 15th December 2001 to 15th January 2002, and overlaying bleaching sites taken by Berkelmans et al. (2004) Masiri et al. highlighted that severe bleaching $(>60 \%)$ generally occurred at inshore reefs in the region of $14-24^{\circ} \mathrm{S}$ and coincided with maximum radiation greater than $28 \mathrm{MJ} \mathrm{m}^{-2}$ day $^{-1}$ along the coast.

Reefs were also partitioned into near-shore and offshore reefs within about $50 \mathrm{~km}$ of the coast (Berkelmans et al. 2004). A total of 172 inshore reefs and 156 offshore reefs were surveyed. An analysis of variance was performed to determine criteria for separation of the two groups of reefs (bleached and unbleached) into those reefs affected by SST, solar radiation and SST + solar radiation. The analysis found that solar radiation was a better discriminator for inshore reef areas but SST is better at discriminating offshore reefs. Reasons given were that for inshore reefs the low tides and low winds in summer increased solar radiation from direct and indirect radiation effects, implying contrasting aerosol effects on solar radiation. A comparison of the 1998 and 2002 mass coral bleaching events in the GBR has found that changes in patterns of bleaching occurred at scales of $\sim 10 \mathrm{~s} \mathrm{~km}$, suggesting that reefs tend to bleach in spatial clusters implicating a solar radiation effect, coupled with variations in local weather conditions, bathymetry, current and tidal conditions (Berkelmans et al. 2004). Several authors have shown that aerosols and atmospheric DMS emissions from coral reefs in this region can be influenced by rising and falling tides over reefs (Bigg and Turvey 1978; Jones and Trevena 2005; Jones et al. 2007; Swan et al. 2012), but our stress experiments now indicate that these emissions could decrease under elevated SSTs. The changes in solar radiation over the GBR described by Masiri et al. (2008) could therefore reflect varying amounts of DMS emitted from the reefs, as the Trade Winds traverse the varying biomass of reefs up and down the east coast of north Queensland, producing changes in direct solar radiation (i.e. solar radiation changes arising from scattering and absorption of radiation) and indirect solar radiation effects (i.e. related to cloud-aerosol microphysical effects) that affect cloud lifetimes and the amount of clouds) (Ramanathan et al. 2001; Barton and Paltridge 1979). Clearly, satellite images show alignment of low level clouds over reefs in the Capricorn-Bunker Group of reefs near Heron Island, and possibly reflect emissions of coral reef produced DMS and organic aerosols (Modini et al. 2009), the precursors of CCN (Fig. 7).

Ramanathan et al. provide examples in the Indian Ocean where industrial aerosols can cause direct and indirect solar radiation forcing, which in some polluted atmospheres can be up to ten times GHG forcing, and one wonders if such warming effects can occur for naturally produced reef aerosols. 


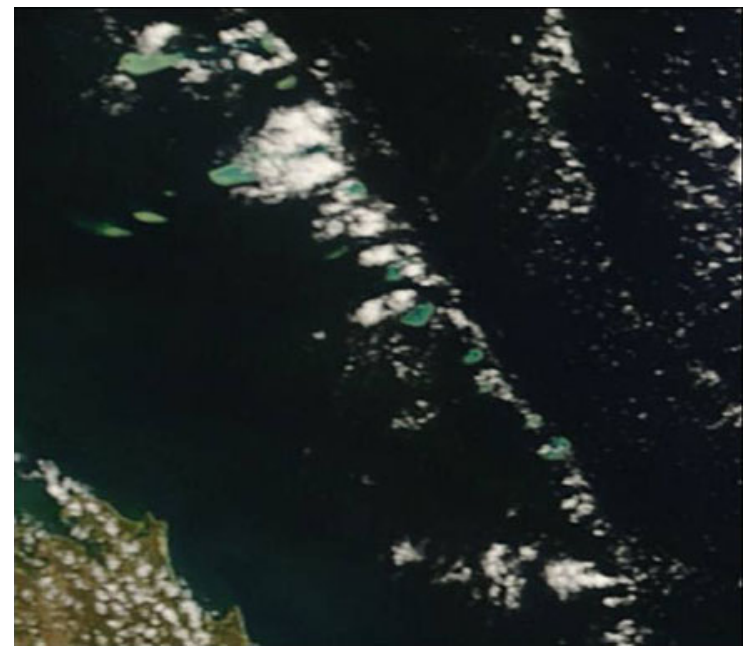

Fig. 7 Cloud cover aligning over the Capricorn-Bunker Group of coral reefs in the Great Barrier Reef, in the vicinity of Heron Island (Source: MODIS picture archived from the 10 February 2007, NASA/GSFC, Rapid Response picture accessed by Melissa Mackeller, University of Queensland)

Field evidence for a shut-down in DMS production during coral bleaching

During January 1994 very high water temperatures $\left(>33^{\circ} \mathrm{C}\right)$, coupled with high air temperatures $\left(45^{\circ} \mathrm{C}\right)$, associated with hot westerly winds, occurred at Nelly Bay reef, Magnetic Island off Townsville $\left(19^{\circ} 10.5^{\prime} \mathrm{S}\right.$, $146^{\circ} .51^{\prime} \mathrm{E}$ ) in the central GBR (Jones et al. 2007). Many colonies of A. formosa at 6-7 m bleached to a pale colour and colonies of Pocillopora damicornis bleached to a bone-white colour (Jones 1995). This author drew attention to the fact that in the heavily bleached branching coral species, the slight tinges of a yellow-brown colour on the undersides of the branches, indicated the effect of solar radiation on the upper surfaces of the coral (Jones 1995). The effects of this bleaching event on DMSP, zooxanthellae and chlorophyll a concentrations in $P$ damicornis tissues was examined (in preparation), as well as monitoring dissolved DMS, DMS flux and DMSPt concentrations at the study site (Curran 1996). During the thermal bleaching event in 1994 zooxanthellae densities in two species of corals (A. formosa, $P$. damicornis) markedly decreased at the sites that displayed extremely high SSTs $\left(30-34^{\circ} \mathrm{C}\right)$ and for these coral species recovery took 2-3 months. Dissolved DMS and DMS flux from the site also markedly decreased during the bleaching event, supporting our chamber experiments (Jones et al. in prepn.). Whilst we have not measured the rates of photooxidation of DMS in the chambers, or loss of DMS due to microbial activity, these chamber experiments support our field studies which have shown a decrease in DMS flux during coral bleaching.

\section{Conclusions}

We believe our research provides evidence that corals do in fact produce atmospheric DMS and this could produce aerosol nanoparticles and possibly $\mathrm{CCN}$ as the studies by Modini et al. (2009) seem to suggest. But as yet further evidence is needed to ascertain whether these DMS aerosol emission from reefs in the GBR could take part in an ocean thermostat as described for the WPWP (Kleypas et al. 2008; Deschaseaux et al. 2012). If corals in the GBR decrease or shut-down production of atmospheric DMS, as our chamber experiments seem to indicate, then reef aerosol particle production could be expected to decrease, reducing $\mathrm{CCN}$ and cloud albedo. This would in turn lead to an increase in solar radiation and an increase in coral bleaching as is now being observed in the GBR (Jones et al. 1997; Berkelmans and Oliver 1999; Berkelmans et al. 2004; Masiri et al. 2008). The central assumption in the DMS-climate feedback hypothesis is that increasing global temperatures would lead to enhanced marine emissions of DMS and therefore increase sulphate aerosol particles and $\mathrm{CCN}$ in the lower atmosphere or marine boundary layer (Charlson et al. 1987). Elevated CCN concentrations effectively increase the number density of cloud droplets, thus influencing cloud albedo (reflected solar energy) and consequently solar radiation dose over the ocean. Our studies therefore suggest that a negative feedback (increased DMSa flux) and a positive feedback (reduced DMSa flux) could occur over coral reefs in the GBR, and that these feedbacks are regulated by SST. As we have stated many times before aircraft flights over the GBR need to be implemented, to measure the physical and chemical characteristics of any reef aerosol emissions (Broadbent and Jones 2006; Jones and Trevena 2005; Jones et al. 2007) and experiments undertaken to ascertain whether these emissions have an effect on SSTs, solar radiation levels and regional climate in the GBR. The increased frequency of mass coral 
bleaching events in the GBR now make these aircraft flights over the GBR imperative.

Acknowledgments Staff at the Heron Island Research Station, and the Australian Institute of Marine Science, are especially thanked for field work assistance, and help with the construction of the seawater chambers used in this study. Dr Evan Weller (University of Tasmania) and Dr Mellisa Mackeller (University of Queensland) are thanked for providing Figs. 2 (MM), 6 (EW) and 7 (MM) which have aided our interpretations. Esther Fischer would also like to thank her family in Switzerland who supported her wish to study Marine Biology in Australia. This research was supported by the Western Mining Corporation and Southern Cross University.

\section{References}

Barton IJ, Paltridge GW (1979) The Australian climatology of biologically effective ultraviolet radiation. Australas J Dermatol 20:68-74

Berkelmans R, Oliver JK (1999) Large scale bleaching of corals on the Great Barrier Reef. Coral Reefs 18:55-60

Berkelmans R, van Oppen MJH (2006) The role of zooxanthellae in the thermal tolerance of corals: 'a nugget of hope' for coral reefs in an era of climate change. Proc R Soc 273:2305-2312. doi:1098/rspb.2006.3567

Berkelmans R, De' ath G, Kinninmonth S, Skirving WJ (2004) A comparison of the 1998 and 2002 coral bleaching events on the Great Barrier Reef: spatial correlation, patterns and predictions. Coral Reefs 23:74-83

Bigg EK, Turvey DE (1978) Sources of atmospheric particles over Australia. Atmos Environ 12:1643. doi:10.1016/ 0004-6981(78)90313-X

Broadbent AD, Jones GB (2004) DMS and DMSP in mucus ropes, coral mucus, surface films and sediment pore waters from coral reefs in the Great Barrier Reef. Mar Freshw Res 55:849-855

Broadbent AD, Jones GB (2006) Seasonal and diurnal cycles of dimethylsulphide, dimethylsulphoniopropionate and dimethylsulphoxide at one tree reef lagoon. Environ Chem 3(260-267):22

Broadbent AD, Jones GB, Jones RJ (2002) DMSP in corals and benthic algae from the Great Barrier Reef. East Coast Shelf Sci 55:547-555

Chancerelle Y (2000) Methodes d'estimation des surface developpees de coreaux scleractiniaires a l'echelle d'une colonie ou d'un peuplement. Oceanol Acta 2(23):211-219

Charlson RJ, Lovelock JE, Andrea MO, Warren SG (1987) Oceanic phytoplankton, atmospheric sulphur, cloud albedo and climate. Nature 326:655

Curran MAJ (1996) The spatial and seasonal distribution of dimethylsulphide and dimethylsulphoniopropionate in the Great Barrier Reef, North Tasman Sea, and Southern ocean regions. PhD Dissertation, James Cook University, p 262

Curran MAJ, Jones GB, Burton HR (1998) Spatial distribution of dimethylsulphide and dimethylsulphoniopropionate in the Australian sector of the Southern Ocean. J Geophys Res 103, No D13, 16,677-16,689
Deschaseaux E, Jones G, Miljevic B, Ristovski Z, Swan H, Vaattovaara P (2012) Can corals form aerosol particles through volatile Sulphur compound emissions. In: Proceedings of the 12th international coral reef symposium, Cairns, 9-13 July

Harriot VJ (1985) Mortality rates of scleractinian corals before and during a mass bleaching event. Mar Ecol Prog Ser 21:81. doi:10.3354/MEPS021081

Hill RW, Dacey JWH, Krupp DA (1995) Dimethylsulphoniopropionate in reef corals. Bull Mar Sci 57:489-494

Hoegh-Guldberg O (1999) Climate change, coral bleaching and the future of the world's coral reefs. Mar Freshw Res 50: 217-224

Jeffrey SS, Humphrey GF (1975) New spectrophotometric equations for determining chlorophylls $a \mathrm{~b}, \mathrm{c}$ and $\mathrm{d}$ in higher plants, algae and natural phytoplankton. Biochem Physio Pflanz 167:191-194

Jones RJ (1995) Sublethal stress assessment in scleractinia and the regulatory biology of the coral-algal symbiosis, $\mathrm{PhD}$ Dissertation, James Cook University, p 140

Jones GB, Curran MAJ, Broadbent AD (1994) Dimethylsulphide in the South Pacific. In: Bellwood O, Choat $\mathrm{H}$, Saxena N (eds) Recent advances in marine science and technology 94. Pacon International \& James Cook University, p 183-190

Jones RJ, Berkelmans R, Oliver JK (1997) Recurrent bleaching of corals at Magnetic Island (Australia) relative to air and seawater temperature. Mar Ecol Prog Ser 158:289-292

Jones GB, Trevena AJ (2005) The influence of coral reefs on atmospheric dimethylsulphide over the Great Barrier Reef, coral sea, Gulf of Papua and Solomon and Bismarck Seas. Mar Freshw Res 56:85-93

Jones GB, Curran MAJ, Broadbent AD, King S, Fischer E, Jones R (2007) Factors affecting the cycling of dimethylsulphide and dimethylsulphoniopropionate in coral reef waters of the Great Barrier Reef. Environ Chem 4:310-322

Kleypas JO, Danabasoglu G, Lough JM (2008) Potential role of the ocean thermostat in determining regional differences in coral bleaching events. Geophys Res Lett, 35, L03613, doi: 10.1029/2007GL032257

Lough JM (2008) Shifting climatic zones for Australia's tropical marine ecosystem. Geophys Res Lett 35:L14708. doi: 10.1029/2008GL034634

Masiri I, Nunez M, Weller E (2008) A ten-year climatology of solar radiation for the Great Barrier Reef: implications for recent mass coral bleaching events. Int $\mathrm{J}$ Rem Sens 29(15):4443-4462

McCleod E et al (2010) Warming seas in the coral triangle: coral reef vulnerability and management implications. Coastal Manage 38(5):518-539. doi:10.1080/08920753. 2010.509466

Modini RL, Ristovski ZD, Johnson GR, He C, Surawski N, Morawska L, Suni T, Kulmala M (2009) New particle formation and growth at a remote, sub-tropical coastal location. Atmos Chem Phys Discuss 9:12101-12139

Oliver J (1985) Recurrent seasonal bleaching and mortality of corals on the Great Barrier Reef. In: Proceedings of 5th international coral reef congress 4, 77-95

Ramanathan V, Collins W (1991) Thermodynamic regulation of ocean warming by cirrus clouds deduced from observations of the 1987 El Nino. Nature 351:27-32 
Ramanathan V, Crutzen PJ, Kiehl JT, Rosenfeld D (2001) Aerosols, climate and the hydrological cycle. Review article. Science 294:2119-2124

Rathke C, Notholt J, Fischer J, Herber A (2002) Properties of coastal Antarctic aerosol from combined FTIR spectrometer and sun photometer measurements. Geophys Res Letts 29:2131. doi:10.1029/2002GL015395

Sunda W, Keiber DJ, Kiene RP, Huntsman S (2002) An antioxidant function for DMSP and DMS in marine algae. Nature 418:317. doi:10.1038/NATURE00851

Swan H, Jones G, Deschaseuax E (2012) Dimethylsulfide and coral reef ecosystems. In: 12th international coral reef symposium, Cairns, 9-13 July

Takahashi Y, Okazaki Y, Sato M, Miyahara H, Sakanoi K, Hong PK, Hoshino N (2010) 27-day variation in cloud amount in the Western Pacific warm pool region and relationship to the solar cycle. Atmos Chem Phys 10:1557-1584
Vallina SM, Simo R (2007) Strong relationship between DMS and the solar radiation dose over the global surface ocean. Science 315:506-508

Van Alstyne K, Schupp P, Slattery M (2006) The distribution of dimethylsulphoniopropionate (DMSP) in tropical Pacific coral reef invertebrates. Coral Reefs 25:321-327

Vogelmann AM, Flateau PJ, Szczodrak M, Markowicz KM, Minnett P (2003) Observations of large aerosol infrared forcing at the surface. Geophys Res Letts 30:1655. doi: 10.1029/2002GL016829

Yost DM, Jones RJ, Mitchelmore CL (2010) Alterations in dimethylsulphoniopropionate (DMSP) levels in the coral Montastraea franksi in response to copper exposure. Aquat Toxicol 98:367-373. doi:10.1016/jaquatox.2010.03.005

Zann LP (2000) North-eastern Australia: the Great Barrier Reef region. In: Sheppard C (ed ) Seas at the Millenium: an environmental evaluation, Chap. 93 